\title{
Too Much Reality? An Ethnographer Looks at Westminster
}

Emma Crewe, The House of Commons: An Anthropology of MPs at Work. Bloomsbury. 2015. 246 pages. ISBN 9781474234580.

Juri Mykkänen, University of Helsinki

Emma Crewe's second book on the British Parliament moves from the "gilded village" of the House of Lords to its opposite, the "manic town" of the Commons. Professor Crewe has made some academic history by being the first scholar ever to produce complete anthropologies of the Houses of Parliament. In many ways, The House of Commons is more interesting of the two for students of politics as the lower chamber is the real arena for representative democracy and all the competitive excitement it contains. Of course, studies on the British Parliament abound; we should not forget Donald Searing's (1993) admirable attempt to capture the inside of Westminster. But where Searing relies mostly on interviews Crewe's take on the subject is based on participatory observation with access to almost everything. Crewe's study is open-ended. Searing, on the contrary, is more focused and theoretically driven (how MPs interpret their various roles).

It is not easy to pass judgment on relative merits of Crewe and Searing (and a few others like him). Yet, for a political scientist Crewe's comprehensive account of "MPs at work" appears often too hasty. The book has many insights and analytical observations, but they are supported by a very scanty literature. The enlightened reader would want more. In spite of this scholastic shortcoming Crewe's book makes a recommended reading to everyone interested in political institutions in action. If anything, The House of Commons is a book that avoids the alienating effect that so often accompanies mainstream political science that fixes its eye only on what can be counted and formally modelled. Not that it would be poor science; it is just too abstract, so much so that the MPs have hard time recognizing their world even after having been explained what it all means.

Crewe worked her way through the Commons gradually during a few years' time, engaging a handful of trusted informants at the outset in 2011. For anyone interested in following Crewe's path, it is advisable to read carefully her account of the field work (see also Crewe 2016). The Westminster has some 5,000 people working there, including $650 \mathrm{MPs}$ who convene, besides their respective parliamentary party groups, in working committees, hearings, and debates; they travel to their single-member constituencies every week and communicate often important issues in the media - more often in social media like Twitter. So how to decide where to go and what to follow? Even more importantly: What is relevant? Obviously everything is relevant if one wants to 
capture parliamentary life in all its various forms and bring forth the complex variety of individual politicians.

Crewe tells a familiar ethnographic story: rely first on people you know, establish good rapport with a few experienced notables, be patient and make sure you have plenty of time. As no-one can be in more than one place at the same time, a participant observer must learn to identify occasions that seem typical and let her informants qualify these assumptions. Saturation and accumulation are the goal. Crewe points out two important sources of information that guided her towards witnessing what is relevant for the Commons: journalists and social media. Journalists are sort of ethnographers whose professional skill is to know what excites the MPs at any one time. They provide a shortcut for the uninitiated. Social media - Twitter and the blogs - are not used by all MPs but an increasing number of them do engage in political debate online. A fair assumption is that online debates and tweets reflect on what takes place inside the parliament. Political importance of an issue is often directly proportional to members' tweets and updates. All along Crewe uses online discussions and comments as evidence.

The book is divided into five main chapters, each covering a major segment of MPs work, and one chapter that discusses MPs motivations and entry into national politics. We learn, among other things, that MPs are more often than not seriously interested in solving social problems or motivated by a firm belief in values. In their constituency surgeries, MPs listen patiently to local worries and often do something to make things right if it is in the MP's power to do so. The cynical portrayal of politicians by the media is not all there is. As Crewe's book nicely demonstrates, political battles inside the Commons can be bloody, yet to see them as just a hording game of spoils is seriously mistaken. Crewe's book also teaches us that MPs cooperate across party lines quite regularly despite the sometimes spiteful public rhetoric from the trenches of government and opposition lines. There is party discipline of course, watched over by the Whips, but here as well as in so many other cases the use of force is a sign of failure. Maintaining party unity is more a matter of finding the right people for the right tasks or using rewards rather than sanctions, and especially being able to anticipate trouble and interfere peacefully in advance. For instance, it is advisable to put an MP with a large following into a ministerial position (even a junior position) than have this person using popularity in voicing complaints from the backbench. Besides, social media have made it more difficult to control what MPs say in public or to stop them from leaking information.

A particularly interesting chapter in Crewe's book is where she describes MPs doings in their constituencies. As I said earlier, a political scientist may dislike this book on the basis of its theoretically quite selective take on the subject. But here the text connects quite nicely with some of the most relevant theories on political representation and the nature of democratic politics. 
For one thing, Crewe notes quite forcefully that MPs do not bow to every direction and try to please everyone. Elsewhere Crewe says that MPs are always canvassing, but these two should not be confused. Seeking support and having a mind of one's own can be reconciled. The tendency to please goes only so far. MPs are eager to engage in discussions with voters but will not go as far as agreeing at the cost of being untrue. By the same token, it is close to impossible to represent the great variety of people and the even greater variety of their views - and often MPs, especially the more experienced, know that. Observations in the field teaches us that here too social hierarchies intervene in the process of representation so that the more established and powerful can have their voices heard better. Crewe also notes that although the descriptive representation style remains strong, it is not always clear that similarity is the driving force of representation. Sometimes it is, other times not.

Representation is not just about political issues and stances; it is also about the person of the representative. Here Crewe brings in a classic in ethnography of politics, Richard Fenno, and his study of U.S. legislators in their constituencies (Fenno 1978). Just like in Fenno's study, the MPs observed by Crewe have to face voters whose main concern is the politician's trustworthiness rather than her views on substantial issues of politics. This relates to the recurrent problem of suspicion of people in power. As politicians recognize this problem well they often try to appear just like their voters - or create an "illusion of closeness". To be an integral part of the constituency is extremely important for MPs. Yet, this bonding behavior can go too far and it comes with a price of ultimately losing the respect of the very same people who are so important in pushing the MP past the post.

Here Crewe claims that an MP is always being pulled in two opposing directions, one towards being "one of us", the other towards being a specialist in politics. If an MP is not trusted as someone who can make a difference (the political specialist) there is no hope for being elected. This leaves both incumbent MPs and aspiring MPs in a contradictory position where a balance must be struck. Further, being "one of us" must be authentic without too much welltrained but impersonal performance. This means that MPs are in fact expected (in some inarticulate manner) to be discriminating in their attention to issues and views and communicate their own position without fear of not including every opinion. Thus, political representation is much more than faithful reflection of interests; more accurately it is about making sense of interests in a twoway relation between the MP and her constituency.

Towards the end the book Crewe uses a case study of legislation to show what it means to call for policies based on evidence. A common yet unsophisticated view tells us that social problems can be solved if we gather all the evidence and design the solution thereafter. When policies fail, according to this view, the reason is in the disregard of evidence or in poor execution of the plan. 96 
This technocratic view is put aside in Crewe's analysis and replaced by a political analysis of evidence. The point is indeed very simple but often difficult to accept: evidence is political and to pretend that is was not would be harmful to democratic process. Every piece of evidence comes with a catch and the more pieces there are the more they open up possibilities to express an interest. Weighing evidence for and against a government bill in the Commons is not about resulting in clear priorities that would transcend all conflicting interests. Nevertheless, evidence is important because it allows the parties to debate an issue from many sides. We learn that solving social problems is never just a matter of knowledge.

Crewe's book on the House of Commons is quite rich in themes that interest political scientists and generally everyone who wants learn about parliaments. It has a good deal of local idioms and some prior knowledge of the British parliamentary system is required. Yet, the book is instructive even for a neophyte reader. It might have benefited from a more thorough dialogue with existing studies that use different methods but still address similar questions.

Finally, The House of Commons bears testimony to the brute fact that ethnographic studies of political institutions are still scholarly exceptions, so much so that less than a decade ago it seemed a good idea to use the expression "toward an anthropology of government" in a book title (Schumann 2009). Considering what it takes to make or break careers in the academia, the paucity in studies similar to Crewe's is of little wonder. The invested amount of work and time may not be very cost effective. This cannot be changed, yet the political ethnographers may help themselves by remembering the standard critique of field work based studies that a lot a thick description is a poor substitute for a thin theory.

\section{References}

CREWE, Emma, 2016. Ethnography of Parliament: Finding Culture and Politics Entangled in the Commons and the Lords. Parliamentary Affairs, 70:1, 155-172.

FENNO, Richard F., Jr., 1978. Home Style: House Members in Their Districts. Boston: Addison-Wesley.

SCHUMANN, William R., 2009. Toward an Anthropology of Government, Democratic Transformations and Nation Building in Wales. New York: Palgrave Macmillan.

SEARING, Donald D., 1993. Westminster's World: Understanding Political Roles. Cambridge, MA: Harvard University Press. 